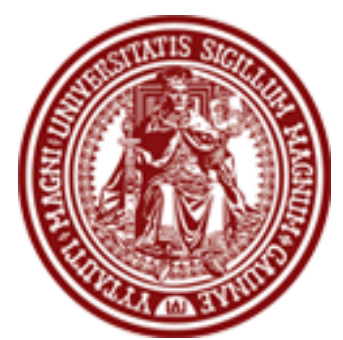

\section{BALTIC JOURNAL OF LAW \& POLITICS}

A Journal of Vytautas Magnus University

VOLUME 9, NUMBER 1 (2016)

ISSN 2029-0454

\title{
POPULISM IN LITHUANIA: DEFINING THE RESEARCH TRADITION
}

\author{
Gintaras Aleknonis \\ Professor; Ph.D. \\ Mykolas Romeris University, Business and Media School (Lithuania) \\ Contact information \\ Address: Ateities 20, LT-08303, Vilnius, Lithuania \\ Phone: +370 52714623 \\ E-mail address: gintaras@gmail.com

\section{Renata Matkevičienè} \\ Associate Professor; Ph.D. \\ Vilnius University, Faculty of Communication (Lithuania)

\section{Contact information} \\ Address: Saulètekio al. 9, LT-10222 Vilnius, Lithuania \\ Phone: +370 52366117 \\ E-mail address: renata.matkeviciene@kf.vu.It
}

Received: January 12, 2016; reviews: 2; accepted: May 16, 2016.

\section{ABSTRACT}

The research on populism and populist political communication in Lithuania is rather limited, regardless of the fact that populist movements and politicians are influential on national and local political levels; they also receive sufficient support from a significant share of the population. Because the Western European research tradition is concentrated on the challenges of right-wing populism, Lithuanian political scientists distinguish right-wing populism as more significant in comparison to left-wing populism. Although Lithuanian 
researchers note, that in the balance of the left-right wing populists, Lithuania stands out with the majority of left-wing populists, in comparison to the popularity and number of rightwing populists in neighbouring countries.

Despite the interest of scholars in various fields of policy research in Lithuania, there is still a lack of research on populist political communication, and what interest does exist is mostly concentrated on analysis of practical issues within the political arena, e.g. the study of the processes of political elections.

The analysis of populist political communication in Lithuania revealed that populism is a relatively oft-mentioned topic in Lithuanian scientific discourse, but in most cases remains on the margins of other research. The theoretical work presents the assumptions based on the analysis of the political situation in Lithuania and examples from other countries. The empirical research of populism is scarce, and in most cases based on content analysis of political documents and media reports.

\section{KEYWORDS}

Populism, political communication, political parties, Lithuania

\section{NOTE}

The authors are members of COST Action IS1308 "Populist Political Communication in Europe: Comprehending the Challenge of Mediated Political Populism for Democratic Politics". 


\section{INTRODUCTION}

The transition from a totalitarian state towards a democracy creates a fertile breeding ground for populism, and Lithuania's case is not an exception. Depending on the definition of populism and methodologies used for calculation, at least approximately one-third of the votes in Lithuanian parliamentary elections can be attributed to political parties that in public and political discourses are defined as populist. Despite today's expansion of the populist rhetoric, no deeper historical roots of populism could be traced in Lithuania. During the two decades of Lithuanian independence between the two World Wars, populism had not evolved into a broader movement and had not received a more precise shape. No party active during this period was called populist; only political rhetoric during election campaigns was identified as "demagogic" or "populist", using these two words as synonyms. ${ }^{1}$ This situation could be described as quite natural, while taking into account that after 1926 parliamentary democracy was suspended in Lithuania. We cannot note any need for populism during the period of the Soviet occupation, when political life was brought under total control of the Communist party, and carefully staged public events or media campaigns became a surrogate of political communication.

The independence movement and disintegration of the Soviet empire brought radical changes to political life in Lithuania, and a populist mood proliferated slowly but surely. Some populist features could be traced to the rhetoric of the leaders of the "Sajūdis" movement, but at the time many more populist decisions were made by the leaders of the local Communist party, who tried to catch the rapid changes in the mood of the population, while "Sajūdis" was the undisputed leader of peoples' hearts and souls. In neighbouring Latvia and Estonia, the independence movements were led by organisations which named themselves "Popular Fronts". In the context of populism research, the very name "Popular Front" (could also be translated as "National Front") could be confusing. Without going into details, we should admit to some interaction between national movements and populism, but direct parallels could be theoretically misleading and practically insulting.

The new boost for populism in Lithuania came at the turn of the twenty-first century. ${ }^{2}$ From 2000, every parliamentary election brought up a new political party that successfully entered the parliament and, in many cases, was able to play the role of the kingmaker. The established (or so-called traditional) political parties

\footnotetext{
${ }^{1}$ Laima Bucevičiūtè, "Seimo rinkimai Lietuvoje 1920-1926 metais: politinès retorikos ypatumai," Darbai ir dienos 53 (2010).

2 Dovaidas Pabiržis, "Populistinès ideologijos partijos Baltijos šalyse 2011-2012 m.," Politikos moks/u almanachas 14, (2013).
} 
were quick to label the new established political parties as populist. Under such circumstances populism gradually acquired a highly negative meaning in Lithuanian public life, and became a sort of hate-word, which is often used (and misused) by politicians in their discussions. Only in exceptional cases can we hear a mainstream politician suggesting that nowadays populism could be an inevitable aspect of political life. ${ }^{3}$

In Lithuania, modern political science recovered only a quarter of a century ago, after a long period of ideological rule of the Communist party. Like most of social research, the political sciences were revived by a young generation of researchers who were originally trained as historians, philosophers, psychologists or lawyers. To some extent, this situation explains some methodological handicaps of Lithuanian political science, but the new generation of researchers have made successful attempts at reintegrating Lithuanian political thought into a broader European tradition. However, political communication received relatively less interest than other fields of policy research, and this interest is mostly concentrated on practical issues, e.g. the study of electoral processes.

The present article is based on a detailed search of the most important Lithuanian databases, ${ }^{4}$ and reveals the peculiarities of the research on populism in Lithuania, exposes the attempts of Lithuanian political scientists to describe the meaning of populism, characterises populist actors as communicators, and defines the links between media and populism, as well as between citizens and populism. We made an attempt to comprehend the entire field of populism and populist political communication research, and we presume that we were able to cover all of the most important publications on this topic. Most of the articles analysed here were written by Lithuanian political scientists, but a few comprehensive publications by foreign researchers as well as of journalists and politicians were taken into account. Only the "journalistic" or "political" articles that were published in materials of scientific conferences or similar collections of articles were analysed.

\footnotetext{
3 Andrius Kubilius, "Populizmas kaip mūsu laiku atspindys": 19; in: Politikos metmenys: demokratinès politikos instituto konferenciju tekstai (Vilnius: Demokratinès politikos institutas, 2000).

${ }^{4}$ For the search of authoritative literature, the most important Lithuanian data bases and catalogues were used: National Database of Humanities and Social Sciences "Lituanistika" // http://www.lituanistikadb.It/; Catalogue of Integrated Information System of Lithuanian Libraries, LIBIS // http://www.libis.It/; Data Bank of National Bibliography, NBDB // http://www.libis.It:8082; Archive of Bibliographical Data Base of Lithuanian Periodicals 1994-2002 // www.Irs.It:10000/bkc/plsal/; Lithuanian Academic Electronic Library, eLABa // www.elaba.It; Lithuanian Archive of Humanities and Social Sciences Data // http://www.lidata.eu/. Special attention was given to the oldest Lithuanian journal devoted to political sciences, "Politologija", and a new almanac of political communication studies "Agora". Because of the peculiarities of the Lithuanian language, the search in the abovementioned databases was conducted using key words (populizmas; populistas; populistai; populistinis; populistinè). The names of prominent populist politicians (Rolandas Paksas; Viktor Uspaskich; Vytautas Šustauskas) and populist political parties (Tvarka ir teisingumas; Darbo partija; Tautos prisikèlimo partija; Drasos kelias) were used as well.
} 
The first part of the article presents the variety of understandings of populism in Lithuania; the second part concentrates on the description of actors in populist political communication. The conclusions summarize the results of the research.

\section{DEFINITIONS OF POPULISM IN LITHUANIAN SCIENTIFIC DISCOURSE}

Lithuanian political scientists publicly acknowledge that it is not simple to define populism in a precise way. ${ }^{5}$ Nevertheless, in the Lithuanian "Political Science Encyclopedic Dictionary", populism is defined as "the political thought and political style, which appeals to the (allegedly) disadvantaged majority or all of society. The people appealed to are encouraged to oppose the political and socioeconomic concentration of power and simple, quick solutions are offered on how to deal with problems". ${ }^{6}$ This definition is supported by L. Donskis and A. Krupavičius, who claim that "populism starts with clarity and the promise of safety and clarity, especially for the society that has lost its belief in safety during crisis and transition periods. (...) The most importantly - promise for order. For the society that is embattled by unemployment, uncertainty, instability, insecurity, social contrasts, criminality, corruption and clash of values the promise of order is important." 7 Their definition of populism stresses promise of safety, clarity, and order in society, which is embattled by unemployment, uncertainty, instability, insecurity, social contrasts, criminality, corruption and clash of values.

However, the former definition of the concept of populism describes the current developments in Lithuanian political system quite well. It is worth noting that populism is described as a style, thus allocating it a reduced status in comparison to an ideology. Nevertheless, it is important that populism is divided into the aspects of political thought (i.e. theoretical, ideological thought) and politicking (i.e. form of communication, worldly actions). It would be difficult to imagine that such a double-sided definition would be attributed to social democracy, conservatism or liberalism. One should also note that in the Lithuanian language, the word politicking clearly has a negative connotation. In this case, a more neutral term such as political activity or political behaviour could have been used. The scientifically neutral encyclopedic definition of populism already codes a negative attitude, which flourishes further in the works of the most influential

\footnotetext{
5 Vladimiras Trimailovas, "Socialinis teisingumas: akistata su "turgaus" libertarizmu," Acta humanitarica universitatis Saulensis, 10 (2010).

6 Živilè Šatūnienè, "Populizmas"; in: Algimantas Jankauskas, ed., Politikos mokslu enciklopedinis žodynas (Vilnius: Vilniaus universiteto leidykla, 2007).

7 Leonidas Donskis and Algis Krupavičius, "Pabaiga: demokratija ir jos kokybė"; in: Algis Krupavičius and Alvidas Lukošaitis, ed., Lietuvos politinè sistema: sąranga ir raida (Kaunas: Poligrafija ir informatika, 2004).
} 
Lithuanian political scientists and political philosophers. This exaggerated negativity towards populism may be due to the fact that up until now, populism has been on the periphery of research in political science and is viewed only as a hindrance for democracy. Therefore, V. Radžvilas emphasises that "populism is overall a destructive phenomenon, to be viewed as a political and social disability of a specific society". Moreover, he warns that "the pure being of it [populism], shows that even the most stable and transparent social and political institutions can someday be destroyed and swallowed by the power of destruction and chaos". ${ }^{8} \mathrm{~L}$. Donskis values populism in the same, unconditionally negative way: "populism becomes highly dangerous and destructive when understood word by word". However, he adds what we could call the sanitary function of populism: "populism warns about the crisis arising from the estrangement of institutions and society's overgrown distrust due to bureaucracy and political arrogance". 9 Interestingly, politicians tend to have a more careful approach towards populism. A. Kubilius, former Prime Minister and former leader of the Conservative party, described the populist mentality slightly more broadly than the philosophers. For him, it is "an instinctive reaction to dramatic changes in the traditional everyday life". According to the politician, "psychologically, the populist mentality is based on the individual and collective inferiority complex, which we can all refer to". ${ }^{10}$

In order to specify the concept of populism in Lithuanian political thought, we can turn to one of the few authors that have explicitly researched populism, namely, D. Pabiržis. According to him, one can look at populism as a: (1) political strategy, (2) political style or form of communication, (3) specific political organization, (4) thin ideology. ${ }^{11}$

Appealing to society would not be the only characteristic of populist political strategy. According to $V$. Laurenas, the populist strategy "rises against the current cohesion of the government as well as the prevailing values and beliefs. [...] populists give rise to a rejuvenating mood and thus inspire people, who, under normal circumstances, would remain apolitical". ${ }^{12}$ A charismatic leader usually turns up in the midst of the populist strategy. ${ }^{13} \mathrm{~L}$. Bielinis underlines the irrationality and emotionalism of populist strategy, ${ }^{14}$ while R. Grigas talks about the

\footnotetext{
8 Vytautas Radžvilas, "Populizmą ir radikalizmą skatinantys veiksniai": 24; in: Politikos metmenys: demokratinés politikos instituto konferenciju tekstai (Vilnius: Demokratinès politikos institutas, 2000).

9 Leonidas Donskis, "Imagologija, manipuliacijos ir viešoji erdvè postmoderniojoje politikoje," Politologija 1 (2004): 29, 30.

10 Andrius Kubilius, supra note 3: 20.

11 Dovaidas Pabiržis, supra note 2.

12 Vaidutis Laurènas, "Politinè krizé Lietuvoje 2003-2004," Politologija 3 (35) (2004): 10.

13 Vytautas Umbrasas, "Populizmas kaip radikalizmo stoka"; in: Politikos metmenys: demokratinès politikos instituto konferenciju tekstai (Vilnius: Demokratinès politikos institutas, 2000).

14 Lauras Bielinis, "Moderniosios šiuolaikinio konservatizmo galimybiu tendencijos"; in: Vladimiras Laučius, ed., Konservatizmo takoskyros (Vilnius: Demokratinès politikos institutas, 2006).
} 
populist tendency "to criticise, yet not engage in positive, proactive deeds". ${ }^{15}$ Populism is also linked to social discontent and radical moods of society: "populist activities are almost always radical. In Lithuania, populism and radicalism are tied, among others, to the society's pursuit of expectations. This society hopes to quickly reach a high standard of living and is, therefore, plainly impatient" ${ }^{16}$

Regarding the political style or communication form of populism, the importance of demagogy should be noted. V. Zeitler talks about demagogical politics, which are close to the people and highly opportunistic. Most importantly, the main goal is to "dramatize the political situation (especially before elections) in order to gain support of the masses. One of the characteristics of political populism is the imprecise, unclear, foggy requirements in their political programme". ${ }^{17}$ Political parties also use some rhetoric techniques, such as simplification, "criticism of the political mainstream, and even accuse other political parties for being populist". ${ }^{18} \mathrm{~L}$. Donskis and A. Krupavičius talk about populism as an anti-politics, because "populism appeals to those lowest and purest instincts of masses". ${ }^{19}$ The populist communication style incorporates a certain secrecy cult, which is based on the notion that we need to act quickly, yet a specific action plan is by no means revealed. Therefore, it is to no surprise that V. Umbrasas states that "we cannot find constructivism or a deeper analysis here [in populism]. There are more unreasonable promises, demagogic slogans and extreme actions than anything else". 20 E. Aleksandravičius makes an effort to parse the difference between demagogy and populism, stating: "some may say that populism and demagogy are one and the same thing. However, there are a few major differences in these categories. Populism is a sort of political doctrine, while demagogy is political behaviour. In the free Lithuanian political market the connection between the two categories could be described as demagogy being the highest form of populism". ${ }^{21}$ A. Navickas bases his argument about "populist politics and a public relations alliance", which openly ignores rules of political culture and bears no thought on measures taken, on the specific example of R. Paksas. "We could call this type of political communication a reality show and lottery hybrid". When communicating, populists "are guided by the belief that it is most important to please the auditorium. Perfected means of persuasion and the fear of melting foundations of

15 Romualdas Grigas, "Teisinès valstybès trikdžiai: civilizacinès negalios Lietuvoje kontūrai," Jurisprudencija 19 (11) (2001).

16 Vaidutis Laurènas, supra note 13: 2.

17 Valentina Zeitler, Populistai ateina ir... išeina?!: Karintijos pamokos (Vilnius: Algimantas, 2004), 9-10.

18 Ilze Balcere, "Comparing Populist Political Parties in the Baltic States and Western Europe," Paper prepared for the 6th ECPR General Conference in Reykjavik (August 25-27, 2011) // http://ecpr.eu/Filestore/PaperProposal/1de703e8-4516-4ed9-92a3-858ed010c393.pdf.

${ }_{19}^{19}$ Leonidas Donskis and Algis Krupavičius, supra note 7.

20 Vytautas Umbrasas, supra note 13: 32.

21 Egidijus Aleksandravičius, Kas iškirto varnui aki: politikos ir visuomenès kritikos etiudai (Vilnius: Versus aureus, 2004), 309. 
values open vast opportunities for manipulation. Lithuanian populism, which once started from 'humanly sensitive' rhetoric, ended up being 'the religion of the society'"'.22 According to I. Balzere, R. Paksas is not a populist, but he uses populist rhetoric, especially "in his public speeches, where he never misses to describe the current state of affairs in imaginative manner". ${ }^{23}$ Populism as communication style is discussed by a group of researchers who published the book Populism in the Baltic States: "These groups [families, youth, pensioners, business people and groups of emigrants] were addressed using the rhetoric more characteristic to political marketing discourse rather than a populist discourse, offering particular benefits to the group (...)".They defined populism as "a tool of the political establishment simply used to manipulate the public". ${ }^{24}$

Discussing the style of populist communication, L. Donskis and A. Krupavičius state that:

Populist often are real masters of social mascaraed and jugglers of political circus perfectly using clownery and show elements. [...] Naturally populist are more likely to consult with image builders and to use their services because they would be recognised as insiders among mans in pubs and public that is savage about everything. And for that specialists for creation of moment ideals and antiideals are needed (the new myth that the elections are won by Its Majesty Image or by "Almighty" public relations) with video clips and half animated tricks that are attacking brains of masses. ${ }^{25}$

In most of the works that analyse the style of populist political communication, the role of populism is related with the low civic participation and engagement of society in politics.

It is obvious, that populism as a form of specific political organization is an insufficiently researched topic in Lithuania. Despite the fact that such influential political actors as the Labour Party or the Order and Justice Party could be described as populist as well as one-person organisations with specific operational techniques, their form of organisation never received a full scale, in depth analysis. Only a short-lived party, The Way of Courage, was researched by L. Mažylis, I. Unikaitè-Jakuntavičienè and B. Ivanovas and labelled as "a single issue protest community". ${ }^{26}$

\footnotetext{
22 Andrius Navickas, "Skaudžios populistinès politikos pamokos": 113; in: Vladimiras Laučius, ed., Tarp dvieju Prezidento rinkimu: 2002-2004 (Vilnius: Demokratinès politikos institutas, 2004).

23 Ilze Balzere, supra note 18.

${ }^{24}$ Mari-Liis Jakobson, ed., Populism in the Baltic States. A Research Report (Tallinn University Institute of Political Science and Governance / Open Estonia Foundation, 2012), 125.

25 Leonidas Donskis and Algis Krupavičius, supra note 7.

26 Liudas Mažylis, Ingrida Unikaitè-Jakuntavičienè, and Bernaras Ivanovas, "The Rise in Popularity of the Lithuanian Political Party Drasos Kelias," Baltic Journal of Law \& Politics 6:1 (2013).
} 
In Lithuania, populism receives the most attention as a thin ideology. In order to "prove, that populism should be foremost referred as a thin ideology", D. Pabiržis refers to Jasper de Raadt and his colleagues in distinguishing "three main characteristics of populist ideology: importance of the people, an anti-elite attitude and instrument suggestions for direct democracy". ${ }^{27} \mathrm{~V}$. Trimailovas prefers to attribute the terrible simplification metaphor to populism and mentions the following characteristics of populist ideology: "demagogy, 'working people' and their 'leader' cult, intolerance for freedom ideals, interpretation of social evils through 'conspiracy theories', etc." 28 Lithuanian researchers do not clearly differentiate between populism as a strategy and ideology in their work; only the idiosyncrasy of populist ideology is underlined. According to V. Laurènas, "populism can mutate - it adapts to various movements and political regimes. It is impossible to describe populism as politically left- or right-winged, because it is a phenomenon, which occurs in every part of the ideological spectrum. Populists can be fierce protagonists for economic liberalism and supporters of state regulation. Populist (anti-)ideology is especially common in post-soviet countries". ${ }^{29} \mathrm{~V}$. Radžvilas uses the term "quasiideology" to label populism, which he describes as the direct link between the state and "the people", which "is the best way to solve social and political problems. Therefore, political institutions, which act as an intermediary between the state and 'the people' are abundant and should be either restricted or abolished altogether". ${ }^{30}$ L. Donskis talks about the direct link of populism with Russian "narodninks" and A. Herzen, therefore, is unsurprisingly of the opinion that populism was born as a half mystic, half radical political doctrine, which ignores political reforms and institutions and instead proposes a direct relationship between the rulers and the people. Because it criticized the state, its institutions and the political elite, populism was popular in Russia and the West alike. ${ }^{31}$

In the current political context in Lithuania, it would be important to have references that would explain how populism is different from totalitarian ideologies, "which destroy their opponents from the outside, while [populism] dismantles if from the inside. [...] Populism is the purified mechanic of gaining and keeping the government power, it is free from values, ideas or moral beliefs. Populist parties can simulate left- or right-winged party values, but sooner or later it ends in the full separation between their words and meanings." 32 Even more, "populism is purely mechanics of capture of authority liberated from all kind of values, ideas and moral

\footnotetext{
27 Dovaidas Pabiržis, supra note 2.

28 Vladimiras Trimailovas, supra note 5: 339.

29 Vaidutis Laurènas, supra note 12: 9.

30 Vytautas Radžvilas, supra note 8: 25.

31 Leonidas Donskis, supra note 9: 29.

32 Ibid. : 32.
} 
obligations". ${ }^{33}$ However, for analysis of populism as an ideology, the statements from I. Balcere could be used. She concludes that in the Baltic States there could be an indication of a "rather narrow form of populism, meaning - antagonism towards elites, centrality of the people and direct democracy, however absent from their ideology are such prophets of western European populist parties as antiimmigrant attitudes, criticism towards globalisation and European Union or nativist ideology". ${ }^{34}$

Based on the analysis of the definitions of populism, two main aspects can be underlined: first, missing understanding and interpretation of populism as an ideology, and it's main relation with antagonism towards elites; ${ }^{35}$ second, in the works of Lithuanian scientists the specificity of populism is stated based on the assumption of the difficulty to prescribe populism for left-wing or right-wing political parties. ${ }^{36}$

These kind of presuppositions arising from a number of Lithuanian research sources show that so-called "empty populism" is prevalent in Lithuania. This concept was coined by Jan Jagers and Stefaan Walgrave. ${ }^{37}$ In order to determine the different sides of populism more precisely, J. Jagers and S. Walgrave created a fourfold typology of populism, which includes: complete populism, excluding populism, anti-elitist populism and empty populism. Application of this scheme in the Lithuanian context leads to the conclusions that some orientation towards "antielitist populism" could be noticed in Lithuania, but it would be complicated to speak about "complete populism" or "excluding populism," since the exclusion of outgroups is not a topic on the national political agenda. However, the recent refugee crisis is creating fertile ground for "excluding populism" and this sort of populism could quickly become an important trend in Lithuanian political discourse.

The study of the definition(s) of populism established in the works of Lithuanian scholars reveals some handicaps of the research field. All of the definitions of populism in Lithuania come from scholars with different attitudes and field of interests: policy research, political philosophy, electoral studies or political communication.

\footnotetext{
${ }^{33}$ Leonidas Donskis amd Algis Krupavičius, supra note 7.

34 Ilze Balzere, supra note 18.

35 Ibid. : 16

36 Vaidutis Laurenas, "Populism as an outcome of post-communist democratic primitivism and procapitalism": 49; in: Alvidas Jankauskas, ed., Lithuania Political Science Yearbook. 2005 (Vilnius: Vilnius University, 2005).

Leonidas Donskis, supra note 10, 32.

37 Jan Jagers and Stefaan Walgrave, "Populism as political communication style: An empirical study of political parties' discourses in Belgium," European Journal of Political Research. 46 (2007).
} 


\section{ACTORS IN POPULIST POLITICAL COMMUNICATION}

Political communication researchers name several actors of political communication that could be related to the manifestation of populism in scientific discourse: politicians and political parties, media and citizens.

\subsection{POPULIST ACTORS AS COMMUNICATORS}

The first thorough research of political parties, carried out immediately after Lithuania regained independence, showed that the influence of populist parties was mediocre, and therefore not much attention was given to its operational or communication peculiarities. In the first decade of independence, A. Krupavičius tried to collect populist and ethnic minority parties into one group, noting that "populist and ethnic minority parties - Freedom Union, Electoral Action of Poles in Lithuania, partially 'Young Lithuania' united up to 100 thousand voters, in other words, $5 \%$ of all active voters". ${ }^{38}$ However, when the same author classified the parties more thoroughly, he categorised them into nine groups, populist parties being among those nine, where the Freedom Union and Republican Party fell into this category. He noted that those parties commonly stated that they hold the values of justice, a united nation and national consciousness. Protest parties were also classified into a separate group by A. Krupavičius. The Humanist, Green and Women's parties were all part of this group; however, they could easily belong to the populist party group as well. While in the first decade of independence there was an unclear line between populist and protest parties, this line completely vanished in the twenty-first century, where all protest parties have been pushed under the wing of populist parties.

When searching for the roots of populism, which could be traced back to the presidential elections in 1997, researchers turn to the levelling variance in political ideologies, differences between the left and right parties. According to V.Laučius:

The first signs of "new politics" appeared in the last decade, when the leftwinged LDDP party (Lithuanian Democratic Labour Party, former Lithuanian Communist Party), who won the elections heavily moved towards the right, and the proceeding winner, Homeland Union party, formerly far right, also drifted towards the left. Overall, they both started proclaiming and acting like two similar centre representatives. The concepts of left and right where muddled and erased - everyone became more or less centrist. ${ }^{39}$

38 Algis Krupavičius, "Pokomunistinè transformacija ir Lietuvos partijos"; in: Algis Krupavičius, ed., Politinès partijos Lietuvoje: atgimimas ir veikla (Kaunas: Litterae Universitatis, 1996).

39 Vladimiras Laučius, "Anapus dešinès ir kairès": 123; in: Vladimiras Laučius, ed., Tarp dvieju Prezidento rinkimu: 2002-2004 (Vilnius: Demokratinès politikos institutas, 2004). 
L. Donskis and A. Krupavičius talk about the presidential as well as political system's crisis situation of year 2003-2004 as a phenomenon which shows the (re)appearance of populism in the Lithuanian political arena, because of President R. Paksas' refusal to collaborate with the Parliament and with the commission of the Parliament in the process of Presidential impeachment and choice of direct communication with the masses. According to L. Donskis and A. Krupavičius this leads toward the discrediting of governmental institutions in the eyes of the masses, then to the personification of the state and identification of the state with its leader and its ruling political party. ${ }^{40}$

Another equally important factor in stimulating populism is the professionalization of PR and its increasing influence. As A. Navickas notes, "the roots of current 'paksism' could be drawn to the start of Artūras Paulauskas career and his slogan: 'We deserve to live better'. The services of PR agencies were used thoroughly during the 1997 presidential elections for the first time. [...] The 'PR genie' was released from the bottle. Lithuanian politics started competing not with ideas or values, but with slogans". ${ }^{41}$

Almost all researchers of the Lithuanian political scene agree that the 2000 Seimas elections became a turning point for populism. During the 1997 presidential elections, A. Paulauskas, the runner up, was accused of populist rhetoric. In 2000 he entered the electoral race into the Seimas with a newly established party, the New Union (social-liberals). Paradoxically, the New Union became part of A. Paulauskas competitor's V. Adamkus's movement's named "new politics". According to V. Laučius:

\begin{abstract}
When President $V$. Adamkus blessed the 'new politics' block in the beginning of 2000 , the roots, from which the non-ideological politics rose, had already begun to grow. Because the left and right border had dissolved and all the parties huddled in the centre, centrism vanished as an alternative for traditional parties like leftist LDDP and rightist Lithuanian Conservative Party, therefore, 'new politics' were needed. Its novelty consisted of the lack of long-term, likeminded politicians and instead invited the rise of popular leaders and importance of short-term interests. ${ }^{42}$
\end{abstract}

V. Uspaskich entered politics with the help of A. Paulauskas. A few years later, in 2004, V. Uspaskich participated in Seimas elections with the new Labour party, which became a model example of left-winged populism in Lithuania. Before the 2012 Seimas elections, the weakened New Union with A. Paulauskas still in the lead merged with the Labour party, thus revealing the ideological affinity of these two

\footnotetext{
40 Leonidas Donskis and Algis Krupavičius, supra note 7: 531.

41 Andrius Navickas, supra note 22: 113.

42 Vladimiras Laučius, supra note 39: 123.
} 
parties and highlighting the populist roots of both sides. From the political communication point of view, V. Uspaskich is one of the most interesting objects for research. R. Paksas is another interesting actor from "new politics", who emerged in 2000. At first he was a conservative, then a member of liberal parties, later founded the Liberal Democrats party, which became the Order and Justice party. Having been president and been taken down through impeachment, R. Paksas is considered the most important right-wing populist. Interestingly, researchers of populism note that in the balance of left and right-wing populists Lithuania stands out with a majority of left-wing populists, in comparison to the popularity and number of right-wing populists in neighbouring countries. ${ }^{43}$ In some academic articles the political party Order and Justice is analysed as a Lithuanian example of a populist party that comes from right-wing populism among Lithuanian parliamentary parties:

The $\Pi$ [Order and Justice political party in Lithuania] is an anti-establishment party that uses a typically populist strategy to juxtapose the people and the 'corrupt' political elite. It advocates for strong state intervention and demands effective law and order, it mainly draws its support from the protest-voter electorate, and its popularity is largely based on the charismatic appeal of its leader, Rolandas Paksas. ${ }^{44}$

According to L. Donskis and A. Krupavičius, populists and interest groups that presents themselves as political parties "simulate what they like - leftists and rightist values, social sensibility, compassion for pure people, but even for thinking teenager it's clear that those are not philanthropic groups or agencies for social sensitivity, but groups of millionaire industrialists and businessmen who without any sentiments manipulate those who are the most disadvantage and exposed". ${ }^{45}$

The Nation Revival party made has been established and participated in the 2008 Seimas elections, and could be considered a new step in populism. Created by TV personalities and entertainers this party could be defined as a protest party and their leaders called accidental politicians. At the height of their polemics, almost all newly formed parties in Lithuania are not only called populist, but also accused of being instruments in the hands of foreign countries. This form of political tactic is usually implemented by the traditional right parties. Due to the fact that the Nation Revival party participated in the coalition and thus allowed the right parties to form the government, the accusations that this party was a tool ceased.

\footnotetext{
43 Zenonas Norkus, "Lietuvos politinè raida: antrojo pokomunistinio dešimtmečio lyginamoji analizė," Politologija 4 (64) (2011).

44 Vesta Ratkevičiūtè and Ainè Ramonaitè, "The Lithuanian Case: National Populism Without Xenophobia"; in: Karsten Grabow and Florian Hartleb, eds., Exposing the Demagogues. Right-Wing and National Populist Parties in Europe (Konrad-Adenauer-Stiftung, 2013).

45 Leonidas Donskis and Algis Krupavičius, supra note 7: 533.
} 
The Way of Courage, a newly formed party before the 2012 Seimas elections, performed relatively well in that round of elections, thus becoming a small challenge for traditional politics. However, it was already the fourth challenge of this sort; therefore, the party, which based its existence one specific incident that had pained the whole country (the so-called Kaunas paedophilia incident), was quickly politically isolated. L. Mažylis, I. Unikaitè-Jakuntavičienė and B. Ivanovas have called this party a single issue protest community. ${ }^{46}$ From the populist political communication point of view, the Parliament elections in 2012 could be an example of possible role and impact of public relations and professionally used populist strategies and populist communication to the results of voting (case of the Labour party).

The examples of parties that emerged in the twenty-first century show that, no matter what goals new parties may have, they are always firstly accused of being populist political parties by the traditional Lithuanian parties. However, it is unlikely that the accusations are true all of the time, because there are signs of protest and natural discontent in Lithuanian society. New parties have to draw attention to themselves, their goals, and values in order to enter the established system and reach their base of voters. This, however, is often mistaken for populism.

One of the first investigations of the Lithuanian political system, the "Impact of change of system of Lithuanian parties to political system," stated that "in quite weak civic societies where are no strong political identification (...) rather often is seen tendency that political elections in (...) could be won by populists or radical politicians who have no clear political structure". ${ }^{47}$ These statements are in some way proved by the research by $A$. Ramonaitè and M. Jastramskis. Their analysis of the political values of political parties showed that as parties the Labour Party, Order and Justice, The Way of Courage and Electoral action of Poles in Lithuania are "in the traditional populist left corner" [as opposite to liberal parties, sociodemocrats and partly conservatives]. ${ }^{48}$ In the "Populism in the Baltic States" the researchers state that "it is visible that populist discourse tends to be more widely presented amongst more marginal parties below the electoral threshold. (...) the key characteristics that seem to unite Lithuanian populists are the aspirations for a strong state and more moral society, but they also aspire for more equality and economic welfare". ${ }^{49}$ As well it could be stated that populism is rather a strategy

\footnotetext{
46 Liudas Mažylis, Ingrida Unikaitè-Jakuntavičienė, and Bernaras Ivanovas, supra note 26.

47 Lietuvos partinès sistemos kaitos itaka politinei sistemai (Vilnius: Pilietinès visuomenès institutas, 2004).

48 Ainè Ramonaitè and Mažvydas Jastramskis, "Vertybès ir isitikinimu struktūros"; in: Kaip renkasi Lietuvos rinkejjai? Idejjos, interesai ir jvaizdžiai politikoje (Vilnius: Vilniaus universiteto leidykla, 2014).

49 Mari-Liss Jakobson, supra note 24.
} 
that often is used not only by "newcomers", but as well by those who "tend to be losing out in the competition".

\subsection{RESEARCH OF THE MEDIA AS AN ACTOR}

Although Lithuania has been part of the European Union for more than a decade, the media sphere remains quite closed up. The confrontation of Russia and the West in 2014 showed Lithuanian vulnerability towards post-communist propaganda. However, during the years of fight for independence, the Lithuanian media gained an almost boundless amount of trust; however, this trust did not stand the test of the free market. During the past decade the trust in media has decreased $^{50}$ and mostly as a result of populist political communication that took place in political and media discourses.

Today, it makes more sense to talk about the decline of quality in the Lithuanian media and the rise of "mediacracy". According to L. Bielinis, "we see the starting formation of a media-political system. A positive space is created for the politician through the channels of media. The media becomes not the helping tool during elections, but an information space, a virtual news field where politics take place, it has all the attributes of real life". ${ }^{51}$

Specific relationships form among new (populist) parties and the media: due to the fact that many new parties enter politics from the business sector, they use outsourcing principles to communicate with the media. ${ }^{52}$ When media publications are "ordered" and paid by political parties, impartial analysis and criticism towards politics disappears altogether. An illusion is formed that the media actively fights new sprouts of populism, when, in fact, it helps the old system, with all its faults, conserve and preserve itself. As V. Laučius notes:

In the post-communist Lithuania, the politicians easily gained foot who viewed politics as a business, thus reaching the highest form of populism. The voters, just like the buyers, are always right, but one can, and should, manipulate them. The new fashion in Lithuanian politics is to make ground for politicians who do not have deep views and beliefs, thus being able to adapt to and

\footnotetext{
50 Mindaugas Degutis, Eurobarometras 72. Visuomenés nuomoné Europos Sajungoje, Šalies ataskaita (2009 m. ruduo). // http://ec.europa.eu/public_opinion/archives/eb/eb72/eb72_It_It_nat.pdf.

51 Lauras Bielinis, supra note 14: 138.

52 Gintaras Aleknonis, "Visuomenè ir žiniasklaida užburtame rate. Nuo sistemos vergo iki 'ketvirtosios valdžios"'; in: Regnum est: 1990 m. Kovo 11-osios Nepriklausomybès Aktui - 20. Liber Amicorum Vytautui Landsbergiui: mokslo straipsniu rinkinys (Vilnius: Mykolo Romerio universiteto Leidybos centras, 2010).
} 
manipulate the voter's wants and moods, while using "political marketing" data

to analyse the behaviour and preferences of voters. ${ }^{53}$

R Paksas's impeachment case (2003-2004) received great attention in the media; numerous analyses about populist politics surrounded the story, and even a few books conceded it. ${ }^{54}$ However, these books could only marginally be called scientific research, as they were written when tempers were high and opinions were baselessly varied. However, due to the fact that the books were written from different points of view, it may be a valuable source of information when examining the relationship between media and politics and their influence on one another.

Problems regarding populist political communication are indirectly grazed when examining politics as a communication game, ${ }^{55}$ the relationship between media and politics, ${ }^{56}$ and election campaigns. ${ }^{57}$

Some scholars stress the watchdog role of the media in relation to the political elite and its presentation in the mass media (media unmasks political elite members, stresses discrepancy between political elite's statements, ideological position and real activities), etc. ${ }^{58}$ Other research stresses the media framing role in political communication and states that cynicism, parody and other media genres have an impact to political communication, and (re)presentation of political actor and political party in media's, political and public discourses. ${ }^{59}$

Some researchers have been analysing political mass media partisanship bias in search for correlation between representation in the mass media of politician and political party. The results of a quantitative representation scale demonstrate the relationship between partisanship bias in representation of political party and political leader of the party, as well the personalisation of political communication in traditional mass media is obvious, in contrary to representation in social media where personalisation of political communication was low. J. Kavaliauskaitè states

53 Vladimiras Laučius, "Mitas ir technologija: Lietuvos pokomunistinès dešinès politiniai archetipai": 38 : in: Vytautas Radžvilas, ed., Lietuvos politinè dešinè: posovietinio reiškinio bruožai (Vilnius: Demokratinès politikos institutas, 2002).

54 Edmundas Ganusauskas, Taikinys Nr. 1 (Vilnius: Lietuviu tauta, 2004); Raimundas Lopata and Audrius Matonis, Prezidento suktukas: politinio proceso Lietuvoje $2003 \mathrm{~m}$. analize (Vilnius: Versus aureus, 2004); Virginijus Savukynas, 'Maištininko' mitologijos: Rolando Pakso ivaizdžiai (Vilnius: Aidai, 2004).

${ }^{55}$ Lauras Bielinis, ed., Politika kaip komunikacinis žaidimas (Vilnius: Vilniaus universiteto leidykla, 2004).

56 Lauras Bielinis, Visuomenè, valdžia ir žiniasklaida: prieštaringa komunikacinè simbiozé (Vilnius: Eugrimas, 2005); Renata Matkevičienè, "Politinio žiniasklaidos diskurso apibrèžtys: žiniasklaidos, kaip politinès komunikacijos demens, tyrimas," Informacijos mokslai 44 (2008); Renata Matkevičienè, "Lietuvos internetinès žiniasklaidos konstruojamo politinio diskurso kaita," Informacijos mokslai 59 (2012).

57 Lauras Bielinis, Prezidento rinkimy anatomija: 2002 metu prezidento rinkimai Lietuvoje (Vilnius: Versus aureus, 2003); Lauras Bielinis, Prezidenté (Kaunas: Knygius, 2011); Gintaras Aleknonis, "European Parliament Elections in Lithuania: Populist Competition in the Shadow of the Presidential Vote," Political Preferences 9 (2014).

58 Irina Kučinskè, "Elito ivaizdžio formavimo ypatumai Lietuvos žiniasklaidoje," Sociologija. Mintis ir veiksmas 2 (2005).

59 Ainè Ramonaitè, Demokratija žiniu visuomeneje: iššūkiu ir galimybiu analizè. Prioritetine kryptis: Piliečiai ir valdymas žiniu visuomeneje (Vilnius, 2007); Regina Koženiauskienè, "Frazeologinis diskursas: manipuliacijos ir kalbos žaidimu galimybès," Lietuviu kalba 2 (2008). 
that the leaders of political parties were dominant in media discourse in comparison with the representation of a particular political party, and especially in the case of controversial political leaders, and in one particular case, the populist politicians $\mathrm{R}$. Paksas, V. Uspaskich, and N. Venckienè. ${ }^{60}$

The analysis of online populism in Lithuania is discussed in the research project "Populism in the Baltic States" where the political scene in social media [Facebook] was analysed. The main conclusion from the analysis stresses that some parties have communicated using "a more populist approach (e.g. Labour Party, Young Lithuania, The Way of Courage, etc.), involving followers in discussion, but also using indoctrination". 61

\subsection{CITIZENS AND POPULISM AS AN OBJECT IN POLITICAL COMMUNICATION RESEARCH}

Citizens' benevolence towards populist political communication has not been studied much at all in Lithuania. Only a few mentions can be found in the research on civil society. Starting from 2007, the Institute for Civil Society has been calculating the index for civil power in Lithuania and continues to perfect the methodology. Based on this research we can indirectly, yet quite precisely draw a conclusion about the influence of populists on the society. In 2005, the same Institute developed a map of civil society in Lithuania, which was included in a book. ${ }^{62}$ This book describes the habits of using media and looks for the reasons behind the discontent with it. Research also tried to determine the effect of information coming from foreign countries on Lithuanians. ${ }^{63}$ This can partially be attributed to research on populist political communication, because newly established parties are likely to be presented as "projects" of unfriendly foreign countries, i.e. their attempt to meddle with Lithuania's politics. The effect of populism is also inevitably mentioned while analysing election results or modern trends of political communication. ${ }^{64} \mathrm{~A}$ short note on the relationship between electoral values and voters' behaviour, and political parties and their ideology, has been provided by A. Ramonaite and M. Jastramskis. They state that in Lithuania the ideological differences on economic issues are quite clear in declarations of political

60 Jūratė Kavaliauskaitè, "Žiniasklaidos tikrovė ir tendencingumas: kaip atrodo politinès partijos ir ju lyderiai?": 260; in: Kaip renkasi Lietuvos rinkèjai? Idèjos, interesai ir ivaizdžiai politikoje (Vilnius: Vilniaus universiteto leidykla, 2014).

61 Mari-Liis Jakobson, supra note 24: 94.

62 Rūta Žiliukaitè, et al., Neatrasta galia: Lietuvos pilietinès visuomenès žemèlapis (Vilnius: Versus aureus, 2006).

63 Ainè Ramonaitè, et al., Tarp Rytu ir Vakaru: Lietuvos visuomenés geokultūrinès nuostatos (Vilnius: Versus aureus, 2007).

64 Inga Vinogradnaitè, ed., Kalbejjimas paraštėse: alternatyvios viešosios erdvès Lietuvoje (Vilnius: Versus Aureus, 2009). 
parties, but in understanding and values of political electoral there is no clear difference - the Lithuanian electorate is more "populist leftist and moral conservative". ${ }^{65}$

As previously stated, only a few fragmented sources can be attached to the investigation of citizens' involvement and participation in political communication, and that research is mostly related with citizens' electoral behavior; but citizens' attention and involvement in populist political communication is still not valued as important scientific research in Lithuania.

\section{CONCLUSIONS}

The search for scientific literature in the most important local data bases and catalogues revealed that in Lithuania populism is a relatively oft-mentioned topic, but in most cases it remains on the margins of research. There are several articles on the topic of populism in Lithuania, but they provide a literature review of foreign authors on populism and some reflection on populism manifestation in Lithuania. Some studies in which political populism in Lithuania is analysed discuss presidential election campaigns, mass media partisanship and bias, populist political leaders, as well introduction of new political parties.

In Lithuanian scientific discourse, political populism is related with political strategy, political style and form(s) of communication, and ideology. Political populism is reviewed in comparison with requirements set for the political system by the citizen society and mostly related with political (Seimas and presidential) elections and the usage of manipulation techniques or tools for image formation, as well the possible damage of political populism to democratic development of Lithuania.

According to political scientists, populism as an ideology in Lithuania could be analysed in the context of all the Baltic States where populism is a "rather narrow form of populism, meaning - antagonism towards elites, centrality of the people and direct democracy, however, absent from their ideology are such prophets of western European populist parties as anti-immigrant attitudes, criticism towards globalisation and European Union or nativist ideology". 66 These arguments strengthen the presupposition that in Lithuania so called "empty populism" is prevalent, while in the analysis of the rhetoric of political parties "anti-elitist populism" could be found.

In Lithuania, as in most post-communist countries, populism is understood as a political style of communication and as a tool to win elections. Populism is related

${ }^{65}$ Ainè Ramonaitè and Mažvydas Jastramskis, supra note 48.

${ }^{66}$ Ilze Balzere, supra note 18. 
more with populist rhetoric that is used by politicians and political parties, mostly by small and new political parties, "to manipulate the public"67 in order to reach their goals (e.g. to gain attention or sympathy for issues that are communicated by politicians or political parties, to get number of votes that is needed be elected, etc.).

As previously mentioned, populism in Lithuania is rather different from populism as understood in Western European practice. It is not related with populist political ideology or specific political parties, but is mostly understood and used by politicians and political parties as a style of political communication seeking to raise interest in some political issues, to increase political participation, especially participation in political elections.

The Paksas case is a salient case of populism in Lithuania when, after the impeachment in 2004 and the topic was extremely politicised, R. Paksas and the party Order and Justice were presented as an example of populism, and especially of populist political communication. As these political actors are on the right of the political spectrum, the image of right-wing populism became the principal topic, and that cast a shadow over all other populist parties, which in Lithuania are more on the left (The New Union, Labour Party) or receive support from all the political spectrum of the voters (The National Revival Party, The Way of Courage).

There are only a few studies of populism in Lithuania based on the analysis of official statements of political parties and their communication language in the social media. The role of political actors, media and citizens in the context of analysis of populism in Lithuania is missing. The main reason for the lack of research on political populism communication is the state of the social sciences in Lithuania: research in political and communication sciences has been based on theoretical assumptions or historiographical research, not empirical investigations of political communication.

\section{BIBLIOGRAPHY}

1. Aleknonis, Gintaras. "European Parliament Elections in Lithuania: Populist Competition in the Shadow of the Presidential Vote." Political Preferences 9 (2014): 39-56.

2. Aleknonis, Gintaras. "Visuomenè ir žiniasklaida užburtame rate. Nuo sistemos vergo iki 'ketvirtosios valdžios'": 673-689. In: Regnum est: $1990 \mathrm{~m}$. Kovo 11osios Nepriklausomybès Aktui - 20. Liber Amicorum Vytautui Landsbergiui:

\footnotetext{
67 Mari-Liis Jakobson, supra note 24.
} 
mokslo straipsniu rinkinys. Vilnius: Mykolo Romerio universiteto Leidybos centras, 2010.

3. Aleksandravičius, Egidijus. Kas iškirto varnui aki: politikos ir visuomenès kritikos etiudai. Vilnius: Versus aureus, 2004.

4. Balcere, Ilze. "Comparing Populist Political Parties in the Baltic States and Western Europe." Paper prepared for the 6th ECPR General Conference in Reykjavik (August 25-27, 2011) //

http://ecpr.eu/Filestore/PaperProposal/1de703e8-4516-4ed9-92a3858ed010c393.pdf.

5. Bielinis, Lauras. "Moderniosios šiuolaikinio konservatizmo galimybiu tendencijos": 133-144. In: Vladimiras Laučius, ed. Konservatizmo takoskyros. Vilnius: Demokratinès politikos institutas, 2006.

6. Bielinis, Lauras. ed. Politika kaip komunikacinis žaidimas. Vilnius: Vilniaus universiteto leidykla, 2004.

7. Bielinis, Lauras. Prezidentè. Kaunas: Knygius, 2011.

8. Bielinis, Lauras. Prezidento rinkimy anatomija: 2002 metu prezidento rinkimai Lietuvoje. Vilnius: Versus aureus, 2003.

9. Bielinis, Lauras. Visuomenè, valdžia ir žiniasklaida: prieštaringa komunikacinè simbiozè. Vilnius: Eugrimas, 2005.

10. Bucevičiūtè, Laima. "Seimo rinkimai Lietuvoje 1920-1926 metais: politinès retorikos ypatumai." Darbai ir dienos 53 (2010): 139-166.

11. Degutis, Mindaugas. Eurobarometras 72. Visuomenès nuomoné Europos Sajungoje. Šalies ataskaita (2009 m. ruduo) // http://ec.europa.eu/public_opinion/archives/eb/eb72/eb72_It_It_nat.pdf.

12. Donskis, Leonidas. "Imagologija, manipuliacijos ir viešoji erdvè postmoderniojoje politikoje." Politologija 1 (2004): 1-36.

13. Donskis, Leonidas, and Algis Krupavičius. "Pabaiga: demokratija ir jos kokybè": 517-534. In: Algis Krupavičius and Alvidas Lukošaitis, ed. Lietuvos politine sistema: sąranga ir raida. Kaunas: Poligrafija ir informatika, 2004.

14. Ganusauskas, Edmundas. Taikinys Nr. 1. Vilnius: Lietuviu tauta, 2004.

15. Grigas, Romualdas. "Teisinès valstybès trikdžiai: civilizacinès negalios Lietuvoje kontūrai." Jurisprudencija 19 (11) (2001): 9-18.

16. Jagers, Jan, and Stefaan Walgrave. "Populism as political communication style: An empirical study of political parties' discourses in Belgium." European Journal of Political Research 46 (2007): 319-345.

17. Jakobson, Mari-Liis, ed. Populism in the Baltic States. A Research Report. Tallinn University Institute of Political Science and Governance / Open Estonia Foundation, 2012. 
18. Kavaliauskaitè, Jūratè. "Žiniasklaidos tikrovè ir tendencingumas: kaip atrodo politinès partijos ir ju lyderiai?": 234-260. In: Kaip renkasi Lietuvos rinkejjai? Idejos, interesai ir ivaizdžiai politikoje. Vilnius: Vilniaus universiteto leidykla, 2014.

19. Koženiauskienè, Regina. "Frazeologinis diskursas: manipuliacijos ir kalbos žaidimy galimybès." Lietuviu kalba 2 (2008) // http://www.lietuviukalba.lt/index.php/lietuviu-kalba/article/view/10/118

20. Krupavičius, Algis. "Pokomunistine transformacija ir Lietuvos partijos": 1-92. In: Algis Krupavičius, ed. Politinès partijos Lietuvoje: atgimimas ir veikla. Kaunas: Litterae Universitatis, 1996.

21. Kubilius, Andrius. "Populizmas kaip mūsu laiku atspindys": 19-23. In: Politikos metmenys: demokratinès politikos instituto konferenciju tekstai. Vilnius: Demokratinès politikos institutas, 2000.

22. Kučinskè, Irina. "Elito ivaizdžio formavimo ypatumai Lietuvos žiniasklaidoje." Sociologija. Mintis ir veiksmas 2 (2005): 55-74.

23. Laučius, Vladimiras. "Anapus dešinès ir kairès": 122-125. In: Vladimiras Laučius, ed. Tarp dvieju Prezidento rinkimu: 2002-2004. Vilnius: Demokratinès politikos institutas, 2004.

24. Laučius, Vladimiras. "Mitas ir technologija: Lietuvos pokomunistinès dešinès politiniai archetipai": 33-67. In: Vytautas Radžvilas, ed. Lietuvos politinè dešinè: posovietinio reiškinio bruožai. Vilnius: Demokratinès politikos institutas, 2002.

25. Laurènas, Vaidutis. "Politinè krizè Lietuvoje 2003-2004." Politologija 3 (35) (2004): 1-34.

26. Laurènas, Vaidutis. "Populism as an outcome of post-communist democratic primitivism and pro-capitalism": 49-84. In: Alvidas Jankauskas, ed. Lithuania Political Science Yearbook. 2005. Vilnius: Vilnius University, 2005.

27. Lietuvos partinès sistemos kaitos itaka politinei sistemai. Vilnius: Pilietinès visuomenès institutas, 2004.

28. Lopata, Raimundas, and Audrius Matonis. Prezidento suktukas: politinio proceso Lietuvoje $2003 \mathrm{~m}$. analizè. Vilnius: Versus aureus, 2004.

29. Matkevičienè, Renata. "Lietuvos internetinès žiniasklaidos konstruojamo politinio diskurso kaita." Informacijos mokslai 59 (2012): 73-83.

30. Matkevičienè, Renata. "Politinio žiniasklaidos diskurso apibrèžtys: žiniasklaidos, kaip politinès komunikacijos dèmens, tyrimas." Informacijos mokslai 44 (2008): 107-117. 
31. Mažylis, Liudas, Ingrida Unikaitè-Jakuntavičienè, and Bernaras Ivanovas. "The Rise in Popularity of the Lithuanian Political Party Drasos Kelias." Baltic Journal of Law \& Politics 6:1 (2013): 63-88.

32. Navickas, Andrius. "Skaudžios populistinès politikos pamokos": 112-114. In: Vladimiras Laučius, ed. Tarp dvieju Prezidento rinkimu: 2002-2004. Vilnius: Demokratinès politikos institutas, 2004.

33. Norkus, Zenonas. "Lietuvos politinè raida: antrojo pokomunistinio dešimtmečio lyginamoji analizè." Politologija 4 (64) (2011): 3-38.

34. Pabiržis, Dovaidas. "Populistinès ideologijos partijos Baltijos šalyse 20112012 m." Politikos moksly almanachas 14 (2013): 115-137.

35. Radžvilas, Vytautas. "Populizmą ir radikalizmą skatinantys veiksniai": 24-31. In: Politikos metmenys: demokratinès politikos instituto konferenciju tekstai. Vilnius: Demokratinès politikos institutas, 2000.

36. Ramonaitè, Ainè. Demokratija žiniu visuomeneje: iššūkiu ir galimybiu analizè. Prioritetine kryptis: Piliečiai ir valdymas žiniu visuomenèje. Vilnius, 2007.

37. Ramonaitè, Ainè, et al. Tarp Rytu ir Vakaru: Lietuvos visuomenès geokultūrinès nuostatos. Vilnius: Versus aureus, 2007.

38. Ramonaitè, Ainè, and Mažvydas Jastramskis. "Vertybès ir isitikinimu struktūros": 126-144. In: Kaip renkasi Lietuvos rinkejjai? Idejjos, interesai ir ¡vaizdžiai politikoje. Vilnius: Vilniaus universiteto leidykla, 2014.

39. Ratkevičiūtè, Vesta, and Ainè Ramonaitè. "The Lithuanian Case: National Populism Without Xenophobia": 263-292. In: Karsten Grabow and Florian Hartleb, eds. Exposing the Demagogues. Right-Wing and National Populist Parties in Europe. Konrad-Adenauer-Stiftung, 2013.

40. Savukynas, Virginijus. 'Maištininko' mitologijos: Rolando Pakso ¡vaizdžiai. Vilnius: Aidai, 2004.

41. Šatūnienè, Živilè. "Populizmas": 106-107. In: Algimantas Jankauskas, ed. Politikos mokslu enciklopedinis žodynas. Vilnius: Vilniaus universiteto leidykla, 2007.

42. Trimailovas, Vladimiras. "Socialinis teisingumas: akistata su "turgaus" libertarizmu." Acta humanitarica universitatis Saulensis 10 (2010): 334-341.

43. Umbrasas, Vytautas. "Populizmas kaip radikalizmo stoka": 32-38. In: Politikos metmenys: demokratinès politikos instituto konferenciju tekstai. Vilnius: Demokratinès politikos institutas, 2000.

44. Vinogradnaitè, Inga, ed. Kalbèjimas paraštèse: alternatyvios viešosios erdvès Lietuvoje. Vilnius: Versus Aureus, 2009.

45. Zeitler, Valentina. Populistai ateina ir... išeina?!: Karintijos pamokos. Vilnius: Algimantas, 2004. 
46. Žiliukaitè, Rūta, et al. Neatrasta galia: Lietuvos pilietinès visuomenès žemèlapis. Vilnius: Versus aureus, 2006. 